\title{
THE SMARTNESS PROFILE OF SELECTED EUROPEAN CITIES IN URBAN MANAGEMENT - A COMPARISON ANALYSIS
}

\author{
Sławomira HAJDUK (D)* \\ Faculty of Engineering Management, Bialystok University of Technology, Bialystok, Poland \\ Received 24 April 2018; accepted 25 September 2018
}

\begin{abstract}
The smart cities concept plays an important role in urban management worldwide as well as should be implemented with the participation of residents and with consideration for their needs. This study examines an analysis of the smartness diversity of European cities on the basis of the International Organization for Standardization 37120 norm dealing with sustainable development of communities. Cities with a higher level of certification exhibit more effective management and their residents show greater commitment to civic life. The assessment of the level of smartness was based on statistics collected by the World Council on City Data using Multidimensional Comparative Analysis. Hellwig's (1968) synthetic indicators were used to create a ranking gauging the level of smartness of European cities which were classified into four groups. The investigation shows large disparities in the smartness of selected European cities.
\end{abstract}

Keywords: territorial management, spatial management, smart city, urban management, ISO37120, European cities.

JEL Classification: M0, M19, C18.

\section{Introduction}

Cities constitute places of innovation, creativity and knowledge worldwide. The approach to urban management is evolving as a result of the above challenges. Implementation of the concept of the smart city becomes a solution to all urban issues. Cities are subject to permanent transformations. Smart, sustainable and inclusive growth is one of the challenges of modern world. It is also a priority of the EU 2020 Strategy. The permanent improvement of the life quality of residents is particularly important in the context of urban areas characterized by a degraded natural environmental and many problems. The need for measurability of smart development is undisputed and does not require justification.

The object of the study was to assess the level of smartness of European cities which have implemented the ISO 37120 norm. The article made use of the Multidimensional

${ }^{\star}$ Corresponding author. E-mail: s.hajduk@pb.edu.pl 
Comparative Analysis method utilizing synthetic meters to compare individual urban centres. The aim of the paper was to present differences in the level of smartness of European cities and to find groups of cities with a similar level of smartness. In the theoretical part of the work, a diagnosis of conditions for smartness in city management was made using the cognitive-critical analysis of desk research with particular emphasis on reports of scientific institutions, international publications and strategic national documents. In the empirical part of the work an assessment of the implementation of the concept of smartness in selected European cities was made using statistical methods.

\section{Background literature}

Cities have become large population centers, as well as global hubs in the flow of capital, knowledge, innovation, specialized business services and consumer trends. On the other hand, cities face many problems, including congestion, environmental pollution and social segregation. The concept of a smart city has been raised in world literature since the nineteenth-century of the last century. Assessment of smartness and classifications of cities are important subject in this issues.

According to European Union (2014), 750 of the largest cities in the world generate 57\% of global GDP. Contemporary researchers have created many models of cities such as the smart city, the digital city, the wired city, the learning city, the sustainable city (Duran-Sanchez, Rio-Rama, Sereno-Ramirez, \& Bredis, 2016). In world literature there is a lack of an explicit definition for the concept of the smart city (Albino, Berardi, \& Dangelico, 2015; Schuler, 2016; Hajduk, 2016). Furthermore, Kobayashi Kaneko, Kniess, Ribeiro Serra, Nogueira Ferraz, and Ruiz (2017) prepared a bibliometric analysis of publications dealing with the smart city. In recent years, many concepts have emerged regarding the urban management, particularly within the concepts of the network model, intellectual capital, e-governance, metropolitan specialization, urban foresight, the cluster, value-based management, reengineering, innovative organization, lean management (Flynn, 2012; Andrews \& Van de Walle, 2013; Ricciardi \& $\mathrm{Za}, 2014)$. Otherwise Pike, Rodriguez-Pose, and Tomaney (2006) claims that the evolution of urban management is an attempt to develop an effective methodology for strategic planning and management of metropolitan and municipal levels.

Local authorities use various tools to stimulate and control the processes taking place within the city. In this regard important concepts include sustainability, knowledge-based organization and intelligent growth forming the foundations of the concept of the smart city. In the past smart city focused on technological aspects and hard infrastructure. The smart city has been defined as an urban intelligence system that connects devices and sensors with increasingly efficient digital telecommunication networks (Zanella, Bui, Castellani, Vangelista, \& Zorzi, 2014; Hu, Li, Ngai, Leung, \& Kruchten, 2014; Rathore, Ahmad, Paul, \& Rho, 2016). Whereas, other definitions focus on social capital (Komninos, 2006; Labra \& Sanchez, 2013). Moreover Dameri and Ricciardi (2015) suggest that smart city is an area of high learning and innovation which fosters creativity through research and development institutions as well as organizations of higher learning. According to Nam and Pardo (2011), the concept of the smart city is linked to such fundamental components as: (I) technology 
factors (intelligent city, ubiquitous city, wired city, hybrid city, information city): physical infrastructure, smart technologies, mobile technologies, virtual technologies, digital technologies; (II) human factors (creative city, learning city, knowledge city): human infrastructure, social capital; (III) institutional factors (smart community, smart growth): governance, policy, regulations, directives.

Definitions of the smart city are various. According to Giffinger (2015) smart city is a well performing, forward-looking city built on the intelligent combination of activities of citizens who are independent and aware. Rios (2008) asserts that smart city is a place for sharing culture, knowledge and life, a city that provides inspiration and motivates its inhabitants to create and thrive within their own lives. Harrison's et al. (2010) approach describes it as an instrumented and interconnected where instrumentation enables the integration of real-time, real-world data through the use of sensors, personal devices, appliances, smart phones, the web, and other similar data-acquisition systems, its interconnectivity allows the integration of that data into the enterprise's computing platform and the communication of such information to various city services while its intelligence refers to the inclusion of modelling, optimizations and visualizations into companies' operational business processes to make better operational decisions. Hollands (2014), on the other hand, suggests that smart city helps to solve problems connected with urbanization especially pollution of environment, land consumption, urban sprawl, transport congestion, energy needs, difficulties related to accessing public services as well as encompasses a diversified set of public initiatives including the creation of better transportation systems, supporting creative innovation and knowledge or development of energy-saving policies. Dirks and Keeling (2009) support the integrated attitude to smart city and emphasize the fact that no system operates in a vacuum. Moreover Komninos (2011) indicated four dimensions of smart city connected with ICT: (I) the application of digital technologies to create a knowledge-based city; (II) the use of ICT to transform inhabitants' life; (III) ingraining of information technology in urban infrastructure; (IV) exploitation of ICT by people to provide growth of innovation. Dameri and Garelli (2014) claim that the smart city implementation requires the participation of various shareholders. Finally, Shapiro's (2006) version argues that quality of life cannot be an isolated feature of smart city because all actions within other dimension should contribute to the improvement of the quality of life.

Current challenges faced by urban centers influence changes in city management. The New Public Management model promotes corporate style of management in the public sector. It moves away from the control of inputs and procedures for the measurement of results in the pursuit of excellence and high quality standards (Baclija, 2012). The Public Governance model builds a civil society and treats citizens as co-decision makers. The Multilevel Governance model includes horizontal and vertical stakeholders in city management (Salet \& Thornley, 2007). The Excellence Quality Management model is based on increasing the competitiveness of cities in the pursuit of excellence (Ntungo, 2007). The Total Quality Management model promotes the achievement of success through the quality activities of its employees. Urban leaders often use outsourcing, crowdsourcing, e-government (Aleksjeczuk \& Sachpazidu-Wójcicka, 2015), benchmarking, metropolitan foresight (Braid, 2001; Roberge, 
2013) and urban specialization. Urban Living Lab supports local authorities in the search for effective ways of solving urban problems using creativity and innovation of city stakeholders (Voytenko, McCormick, Evans, \& Schliwa, 2016).

An important strategic document referring to a citie's smart sustainability is the local spatial development plan. Unfortunately, many Polish cities have not created such plans. Average planning coverage is $49.6 \%$ for cities (30.2\% for Poland) and $15.6 \%$ of areas have only a project of such plan. Additionally, planning coverage is characterized by great diversity, for instance Lodz is covered by plans in only 16.1\%, but Gdansk - 65.4\% (Hajduk, 2018). Lack of spatial development plans causes chaotic development and urban sprawl of cities (Howe \& Langdon, 2002; Fertner, Jørgensen, T. A. S. Nielson, \& K. S. B. Nilsson, 2016). An important issue is the development of sustainable transport in the context of spatial management. Contemporary cities need to better use available technical and organizational solutions to improve the current urban transport situation (Hajduk, 2017). Furthermore, citizens' participation should become the base for all strategic decision-making (Antunes, Sapateiro, Zurita, \& Baloian, 2010; Horelli, 2013).

Literature contains many procedures for testing a city's performance and numerous organizations and institutions have prepared city rankings (Institute for Urban Strategies, 2016) in particular relating to the life quality. Foundations for the study and measurement of smart city has been created by Giffinger et al. (2007). The most intelligent cities turned out to be Luxembourg, Aarhus and Turku. Kearney (2017), on the other hand, developed his Global Cities Index on the basis of the following factors: economic activity, human capital, information exchange, cultural experience and political commitment. In turn, Lombardi's, Giordano, Farouh, and Yousef (2012) approach to measuring determinants of urban development is reflected in his analysis sixty urban features through the use of the Analytic Network Process. The author identified entrepreneurship and innovation as the most important features of urban development. Moreover, Caragliu, Del Bo and Nijkamp (2011) argued that the presence of the creative class and transport accessibility significantly influence urban development. The issue of urban development factors is extensively described in literature. Innovation, entrepreneurship and creativity are its most important determinants. Furthermore, CITYkeys suggested five themes of smart city: people, the planet, prosperity, governance and propagation (Bosch et al., 2017). Cohen (2012) identified 62 indicators of the six components of the Smart Cities Wheel such as safe, healthy, energy, urban planning. Whereas, Neirotti, De Marso, Cagliano, Mangano, and Scorrano (2014) indicated twelve domains which are highlighted in a number of urban development studies and whose main features include natural resource and energy, transport and mobility, buildings, living, government and economy, people. He (2017) construct an evaluation index system based on the Analytic Hierarchy Process which is suitable to Chinese conditions. Moreover Dall'O', Bruni, Panza, Sarto, and Khayatian (2017) create a methodology for assessing smartness used for medium and small cities in northern Italy. In scientific literature there are a lot of methods to measure a smart city. In this context it is important finds classification of European cities. Table 1 presents the most popular ranking of smart cities. The leaders are London, Paris and New York in five rankings. 
Table 1. Characteristic of the most popular ranking of smart cities

\begin{tabular}{|l|l|l|}
\hline \multicolumn{1}{|c|}{ Name } & \multicolumn{1}{|c|}{ Important cities } & \multicolumn{1}{c|}{ Domains of indicator } \\
\hline $\begin{array}{l}\text { Global Smart } \\
\text { City Perfor- } \\
\text { mance }\end{array}$ & $\begin{array}{l}\text { Singapore, London } \\
\text { (UK), New York } \\
\text { (USA) }\end{array}$ & Mobility, healthcare, public safety and productivity \\
\hline $\begin{array}{l}\text { Global Cities } \\
\text { Ranking }\end{array}$ & $\begin{array}{l}\text { London (UK), New } \\
\text { York (USA), Paris } \\
\text { (France) }\end{array}$ & $\begin{array}{l}\text { Business activity, human capital, information exchange, } \\
\text { cultural experience and political engagement }\end{array}$ \\
\hline $\begin{array}{l}\text { Ranking of Cit- } \\
\text { ies in Motion }\end{array}$ & $\begin{array}{l}\text { New York (USA), } \\
\text { London (UK), Paris } \\
\text { (France) }\end{array}$ & $\begin{array}{l}\text { Economy, human capital, technology, environment, in- } \\
\text { ternational outreach, social cohesion, mobility and trans- } \\
\text { port, governance, urban planning, public management }\end{array}$ \\
\hline $\begin{array}{l}\text { Ranking of } \\
\text { World Cities }\end{array}$ & $\begin{array}{l}\text { London (UK), New } \\
\text { York (USA), Tokyo } \\
\text { (Japan) }\end{array}$ & $\begin{array}{l}\text { Advanced business services such as financial, account- } \\
\text { ing, consulting, legal, advertising }\end{array}$ \\
\hline $\begin{array}{l}\text { Global Power } \\
\text { City Index }\end{array}$ & $\begin{array}{l}\text { London (UK), New } \\
\text { York (USA), Tokyo } \\
\text { (Japan) }\end{array}$ & $\begin{array}{l}\text { Economy, R\& D, cultural interaction, livability, environ- } \\
\text { ment, accessibility }\end{array}$ \\
\hline $\begin{array}{l}\text { Innovation Cit- } \\
\text { ies Global Index }\end{array}$ & $\begin{array}{l}\text { London (UK), New } \\
\text { York (USA), Tokyo } \\
\text { (Japan) }\end{array}$ & $\begin{array}{l}\text { Cultural assets, human infrastructure, networked mar- } \\
\text { kets }\end{array}$ \\
\hline
\end{tabular}

Note: author's elaboration on the basis of Juniper Research (2017), A.T. Kearney (2017), IESE (2017), Globalization and World Cities (2016), The Mori Memorial Foundation (2017).

The most popular model of smart city are International Organization for Standardization 37120: Sustainable Development of Communities (ISO), British Standards Institute Maturity Model (BSI) and International Data Corporation MaturityScape (IDC). Lynch (2015) suggest that the ISO 37120:2014 standard helps to compare cities in terms of urban service performance and quality of life. World Council on City Data (WCCD) Open Data Portal, based on the ISO 37120 international standard of city data, allows the examination and monitoring 46 member cities (Steele, 2014; Fox, 2015; McCarney, 2015). Table 2 presents individual regions of the world along with selected cities which are connected in the WCCD. The most cities are from Europe (31\%) and North America (30\%). According to Marsal-Llacuna (2015), the ISO 37120 norm has used 46 basic and 54 additional indicators including 17 thematic groups. Appendix 1 shows their characteristics in relation to fundamental indicators. The most indicators (together 10) have the solid waste. The waste water consists of only 5 core indicators.

Table 2. List of Smart Cities

\begin{tabular}{|c|l|}
\hline Regions & \multicolumn{1}{|c|}{ Cities (Country) } \\
\hline Europe & $\begin{array}{l}\text { Amsterdam (Netherlands), Eindhoven (Netherlands), Heerlen (Netherlands), Rot- } \\
\text { terdam (Netherlands), Zwolle (Netherlands), Helsinki (Finland), London (United } \\
\text { Kingdom), Koprivnica (Croatia), Zagreb (Croatia), Aalter (Belgium), Gdynia (Poland), } \\
\text { Barcelona (Spain), Valencia (Spain), Porto (Portugal), Sintra (Portugal) }\end{array}$ \\
\hline Asia & $\begin{array}{l}\text { Shanghai (China), Amman (Jordan), Dubai (United Arab Emirates), Haiphong (Viet- } \\
\text { nam), Jamshedpur (India), Pune (India), Surat (India), Makati (Philippines), Makkah } \\
\text { (Saudi Arabia), ArRiyadh (Saudi Arabia), Taipei (Taiwan) }\end{array}$ \\
\hline
\end{tabular}


End of Table 2

\begin{tabular}{|l|l|}
\hline \multicolumn{1}{|c|}{ Regions } & \multicolumn{1}{c|}{ Cities (Country) } \\
\hline Africa & Johannesburg (South Africa), Tshwane (South Africa), Minna (Nieria) \\
\hline $\begin{array}{l}\text { America } \\
\text { North }\end{array}$ & $\begin{array}{l}\text { Boston (USA), Los Angeles (USA), Oakville (USA), San Diego (USA), Cambridge } \\
\text { (Canada), Saint-Augustin-de-Desmaures (Canada), Shawinigan (Canada), Surrey } \\
\text { (Canada), Toronto (Canada), Vaughan (Canada), Guadalajara (Mexico), Leon (Mexico) }\end{array}$ \\
\hline $\begin{array}{l}\text { America } \\
\text { South }\end{array}$ & Bogota (Colombia), Bueno Aires (Argentina) \\
\hline Oceania & Brisbane (Australia), Greater Melbourne (Australia), Melbourne (Australia) \\
\hline
\end{tabular}

Note: author's elaboration on the basis of (World Council on City Data, 2017).

\section{Material and methods}

The empirical material in this study was based on currently available statistical data listed by the World Council on City Data between 2014 and 2017. The measurement of socioeconomic development is very complex due to the wide range of factors. Hence, the development level of European cities' was investigated through the application of the Multivariate Comparative Analysis method and the linear ordering of objects, developed originally by Hellwig and allowing the creation of ranking of objects measured using multiple variables. Through in this method objects being studied are arranged on the basis of their distance from the established reference object.

Hellwig's synthetic indicator was created on the basis of diagnostically selected variables relating to substantive, formal and statistical criteria. In this investigation significance, the level of variability and the level of correlation of variable pairs were important. The final set of diagnostic variables described the cities' economic situation as well as their inhabitants' social conditions. In relation to formal assumptions selected variables are characterized by measurability, completeness and accessibility. Statistically criteria concerns an appropriate level of variable variation and exhibit a low correlation between them (Guyon \& Elisseeff, 2003). The level of variation was calculated using the following formula (Panek, 2009):

$$
V=\frac{S_{X j}}{\overline{x_{j}}} \cdot 100 \%,
$$

where: $V$ - the coefficient of variation; $S_{X j}$ - the standard deviation of $j$-th variable; $j$ - the number of variables; $\overline{x_{j}}$ - the mean value of $j$-th variable.

Next, variables with a coefficient of variation below $10 \%$ were eliminated and correlations between remaining variables were calculated using Pearson's correlation coefficient whose critical value was establish as the absolute value of 0.5 . Variables with value slower than this threshold were selected for analysis and, in the end, twelve variables were identified:

$X_{1}$ - share of students completing secondary education [\%];

$X_{2}$ - ratio primary education students to teacher [-];

$X_{3}$ - number of total residential electrical energy use per capita [kWh/yr/capita];

$X_{4}$ - number of natural disaster related deaths per 100 thousands of population [units/100,000/yr]; 
$X_{5}$ - number of in-patient hospital beds per 100,000 of population [units/100,000];

$X_{6}$ - under age five morality per 1,000 of live births [units/1,000];

$X_{7}$ - number of homicides per 100,000 of population [units/100,000/yr];

$X_{8}$ - share of city population living in slums [\%];

$X_{9}$ - number of cell phone connections per 100,000 of population [units/100,000];

$X_{10}$ - length of high capacity public transport system per 100,000 of population [kilometres /100,000];

$X_{11}$ - number of public transport trips per capita in year [units/capita/yr];

$X_{12}$ - share of the city's wastewater receiving tertiary treatment [\%].

It is important to determine the nature of the objects describing variables. Stimulants are variables whose high value means a favorable level of researched phenomenon development. On the other hand, inhibitors are variables whose high values signal a negative impact on the phenomena being studied. Characteristics $X_{2}, X_{3}, X_{4}, X_{6}, X_{7}, X_{8}$ were identified as inhibitors while the rest were accepted as stimulants. A numerical description of the set of objects can be presented as an observation matrix:

$$
X=\left[\begin{array}{cccc}
x_{11} & x_{12} & \ldots & x_{1 m} \\
x_{21} & x_{22} & \ldots & x_{2 m} \\
\ldots & \ldots & \ldots & \ldots \\
x_{n 1} & x_{n 2} & \ldots & x_{n m}
\end{array}\right],
$$

where: $x_{i j}$ - the value of $j$-th characteristic for $i$-th object $(i=1,2, \ldots, n ; j=1,2, \ldots, m)$.

On account of the variables' various units and values the next step involved the normalization of selected variables. The arithmetic mean of the $j$-th characteristic $\left(\overline{x_{j}}\right)$ and the standard deviation of the $j$-th characteristic $\left(s_{x j}\right)$ were calculated using the method of standardization having the following formula (Panek, 2009):

$$
z_{i j}=\frac{X_{i j}-\overline{X_{j}}}{S_{X j}} .
$$

These transformations resulted in the creation of a matrix of standardized values of characteristic $Z$ :

$$
Z=\left[\begin{array}{cccc}
z_{11} & z_{12} & \ldots & z_{1 m} \\
z_{21} & z_{22} & \ldots & z_{2 m} \\
\ldots & \ldots & \ldots & \ldots \\
z_{n 1} & z_{n 2} & \ldots & z_{n m}
\end{array}\right],
$$

where $z_{i j}$ - the standardized values of $x_{i j}$.

And finally, Euclidean distances between the object and the ideal object $P_{o}\left(c_{i o}\right)$ were calculated using the following formula (Młodak, 2006):

$$
c_{i o}=\sqrt{\sum_{j=1}^{n}\left(z_{i j}-z_{o j}\right)^{2}},
$$

where: $z_{o j}=\left\{\begin{array}{l}\max _{i}\left\{z_{i j}\right\}, \text { for stimulants } \\ \min _{i}\left\{z_{i j}\right\}, \text { for destimulants }\end{array}\right.$. 
In the last step Hellwig's synthetic indicator $\left(d_{i}\right)$ was determined utilizing the following formula (Lesot, 2006):

$$
d_{i}=1-\frac{C_{i o}}{C_{o}}, \quad(i=1,2, \ldots, n),
$$

where: $C_{o}=\overline{C_{o}}+2 S_{o}-$ the critical distance between the object and the "ideal object".

Moreover, to simplify comparisons between the development levels of cities a modification of Hellwig's synthetic indicator $\left(d_{i}^{\prime}\right)$ according to the following formula was applied (Hellwig, 1968):

$$
d_{i}=\frac{d i}{d i \max } \cdot 100 \%,
$$

where: $d i \max$ - the maximum value of the synthetic indicator.

The transformed indicator for the most developed city, therefore, is assigned a value of 100. Hellwig's synthetic indicator $\left(d_{i}\right)$ was calculated for each object (city) and a positive value from 0 to 1 was assumed. The higher the level of synthetic the indicator the more favorable the situation of the object. Next, the European cities were ordered linearly. Their classifications were determined on the basis of the mean value of the synthetic indicator $\left(\overline{d_{i}}\right)$ and its standard deviation $\left(S_{d i}\right)$ with typological classes specified through the creation of four separate groups of similar objects (Młodak, 2006):

Group I: if the synthetic indicator is $d_{i}>\bar{d}_{i}+S_{d i}$;

Group II: if the synthetic indicator is $\overline{d_{i}} \leq d_{i}<\overline{d_{i}}+S_{d i}$;

Group III: if the synthetic indicator is $\overline{d_{i}}-S_{d i} \leq d_{i}<\overline{d_{i}}$;

Group IV: if the synthetic indicator is $d_{i} \leq \bar{d}_{i}-S_{d i}$.

\section{Results and discussion}

The investigation started out with 46 diagnostic variables which, after verification, were reduced to twelve representing nine areas: education $\left(X_{1}, X_{2}\right)$, energy $\left(X_{3}\right)$, fire and emergency response $\left(X_{4}\right)$, health $\left(X_{5}, X_{6}\right)$, safety $\left(X_{7}\right)$, shelter $\left(X_{8}\right)$, telecommunication and innovation $\left(X_{9}\right)$, transportation $\left(X_{10}, X_{11}\right)$, wastewater $\left(X_{12}\right)$. The analysis covered fourteen European cities selected from 46 cities worldwide having an ISO 37120 certificate.

Table 3 presents statistical characteristics of diagnostic variables. Analyzed variable values of individual cities were characterized by different degrees of differentiation. Coefficient of variation values ranged from approximately $18 \%$ to nearly $374 \%$. The greatest variance between cities was seen in the number of natural disaster related deaths per 100,000 of population. The smallest divergence was observed in the variable describing the share of students completing secondary education.

Synthetic measures of development $\left(\mathrm{d}_{\mathrm{i}}\right)$ were defined for each city. Results of calculated synthetic measures and the order of cities in relation to the basic level of socio-economic development are summarized in Table 4. Synthetic measurements have shown great variances with values ranging from 0.293 to 0.006 . The synthetic measure for the city with the highest level of development was almost a hundred times higher than the synthetic measure of the 
city with the lowest level of development. This means that the analyzed European cities are very different in terms of their level of socio-economic development. Values of synthetic measures of seven cities exceeded the average value. This group included Aalter, Zagreb, Zwolle, Porto, Gdynia, Barcelona and Eindhoven. Seven other cities were characterized by a level of socio-economic development which fell below the average. One Polish city (Gdynia) attained a weak position and was classified in Group IV.

Table 3. Statistical characteristics of diagnostic variables

\begin{tabular}{|c|c|c|c|l|l|}
\hline $\begin{array}{c}\text { Vari- } \\
\text { ables }\end{array}$ & Average $(\bar{x})$ & $\begin{array}{c}\text { Standard de- } \\
\text { viation }\left(S_{X}\right)\end{array}$ & $\begin{array}{c}\text { Coefficient of } \\
\text { variety } V[\%]\end{array}$ & \multicolumn{1}{|c|}{ Maximum } & \multicolumn{1}{|c|}{ Minimum } \\
\hline$X_{1}$ & 82.6 & 14.5 & 17.6 & 101.6 London & 51.6 Sintra \\
\hline$X_{2}$ & 16.8 & 3.8 & 22.5 & 22.7 Barcelona & 11.5 Zagreb \\
\hline$X_{3}$ & $1,367.1$ & 313.5 & 22.9 & $1,921.0$ Porto & 830.9 Gdynia \\
\hline$X_{4}$ & 0.4 & 1.6 & 374.2 & 6.1 Heerlen & 0.0 Sintra \\
\hline$X_{5}$ & 619.6 & 390.5 & 63.0 & $1,641.2$ Porto & 0.0 Aalter \\
\hline$X_{6}$ & 3.3 & 1.9 & 56.0 & 6.8 Rotterdam & 0.0 Aalter \\
\hline$X_{7}$ & 1.0 & 0.9 & 91.0 & 3.2 Rotterdam & 0.0 Aalter \\
\hline$X_{8}$ & 0.3 & 0.8 & 312.7 & 3.2 Amsterdam & 0.0 Valencia \\
\hline$X_{9}$ & 101,211 & 31944.0 & 31.6 & $146,892 Z$ Zwolle & $36,074.8$ Koprivnica \\
\hline$X_{10}$ & 20.4 & 31.1 & 152.2 & 121.1 Aalter & 0.0 Koprivnica \\
\hline$X_{11}$ & 236.7 & 200.5 & 84.7 & 625.7 Porto & 0.01 Koprivnica \\
\hline$X_{12}$ & 56.4 & 48.0 & 85.0 & 100.0 Heerlen & 0.0 Gdynia \\
\hline
\end{tabular}

Note: author's elaboration on the basis of (World Council on City Data, 2017).

Table 4. The level of socio-economic development

\begin{tabular}{|c|l|c|c|}
\hline \multirow{2}{*}{ Rating } & \multicolumn{1}{|c|}{ Cities, country } & $d_{i}$ & $d_{i}^{\prime}$ \\
\hline 1 & Heerlen, Netherland & 0.293188 & 100.00 \\
\hline 2 & Amsterdam, Netherland & 0.264161 & 90.10 \\
\hline 3 & London, United Kingdom & 0.262725 & 89.61 \\
\hline 4 & Porto, Portugal & 0.209468 & 71.45 \\
\hline 5 & Zwolle, Netherland & 0.186595 & 63.64 \\
\hline 6 & Rotterdam, Netherland & 0.178828 & 60.99 \\
\hline 7 & Barcelona, Spain & 0.176798 & 60.30 \\
\hline 8 & Eindhoven, Netherland & 0.17596 & 60.02 \\
\hline 9 & Valencia, Spain & 0.157182 & 53.61 \\
\hline 10 & Aalter, Belgium & 0.117781 & 40.17 \\
\hline 11 & Zagreb, Croatia & 0.094444 & 39.98 \\
\hline 12 & Koprivnica, Croatia & 0.090723 & 30.94 \\
\hline 13 & Gdynia, Poland & 0.057186 & 19.50 \\
\hline 14 & Sintra, Portugal & 0.006007 & 2.05 \\
\hline
\end{tabular}

Note: author's elaboration on the basis of (World Council on City Data, 2017). 
The highest level of socio-economic development was achieved by the city of Heerlen with Sintra showing the lowest level of development. The class of cities having the highest level of development also included Amsterdam and London. Group II included five cities (Porto, Zwolle, Rotterdam, Barcelona, Eindhoven) with a relatively high level of development. Group III contained four cities (Valencia, Aalter, Zagreb, Koprivnica) characterized by low levels of development. Bringing up the rear were two cities of Group IV, presenting the lowest level of socio-economic development: Gdynia, Sintra. Table 5 shows the classification of European cities by their level of development.

Table 5. The classification of European cities by their level of development

\begin{tabular}{|c|l|l|}
\hline Groups & \multicolumn{1}{|c|}{ Ranges } & \multicolumn{1}{|c|}{ Cities } \\
\hline I & $d_{i}>0.245$ & Heerlen, Amsterdam, London \\
\hline II & $0.163<d_{i} \leq 0.245$ & Porto, Zwolle, Rotterdam, Barcelona, Eindhoven \\
\hline III & $0.082<d_{i} \leq 0.163$ & Valencia, Aalter, Zagreb, Koprivnica \\
\hline IV & $d_{i} \leq 0.082$ & Gdynia, Sintra \\
\hline
\end{tabular}

Note: author's elaboration on the basis of (World Council on City Data, 2017).

The characteristic of variables describing the level of socio-economic development of each group presented in Table 6. The number of in-patient hospital beds per 100,000 of population in cities from Group I is two times lower than that of cities Group II. The share of the city's wastewater receiving tertiary treatment is similar for I, II and III groups of cities. The number of homicides per 100,000 of population in cities from Group IV cities is the greatest. The length of high capacity public transport system per 100,000 of population in cities from Group III is two and half times higher than in those of Group I.

Table 6. Average values of variables describing the level of socio-economic development

\begin{tabular}{|c|c|c|c|c|}
\hline Variables & Group I & Group II & Group III & Group IV \\
\hline$X_{1}$ & 92.6 & 77.7 & 88.6 & 69.0 \\
\hline$X_{2}$ & 19.0 & 17.6 & 16.0 & 12.8 \\
\hline$X_{3}$ & $1,318.7$ & $1,349.5$ & $1,448.7$ & $1,320.7$ \\
\hline$X_{4}$ & 2.0 & 0.0 & 0.0 & 0.0 \\
\hline$X_{5}$ & 483.3 & 825.9 & 593.9 & 359.7 \\
\hline$X_{6}$ & 4.2 & 3.5 & 3.2 & 1.8 \\
\hline$X_{7}$ & 1.3 & 1.3 & 0.2 & 1.6 \\
\hline$X_{8}$ & 1.2 & 0.0 & 0.05 & 0.02 \\
\hline$X_{9}$ & $129,953.7$ & $114,012.9$ & $81,656.3$ & $65,201.0$ \\
\hline$X_{10}$ & 13.3 & 19.0 & 34.7 & 6.3 \\
\hline$X_{11}$ & 297.6 & 321.6 & 132.8 & 141.8 \\
\hline$X_{12}$ & 66.7 & 65.4 & 65.4 & 0.8 \\
\hline
\end{tabular}

Note: author's elaboration on the basis of (World Council on City Data, 2017). 


\section{Conclusions}

The smart city is a multidimensional concept and the use of the taxonomic method to assess its level is justified. Assessment of smartness of cities was exceptionally challenging, due both to the complexity of the phenomenon as well as in the difficulty of measuring the values of diagnostic variables. In this study the level of smartness of European cities having an ISO 37120 certificate was examined through the application of Hellwig's synthetic indicator of development. Conducted research allowed the formulation of the following conclusions. European cities with an ISO 37120 certificate vary strongly in terms of their level of smartness. The city of Heerlen is a definite leader of this ranking while the city of Sintra brings up the rear. In addition a top position in highly reputed city ranking helps to improve the image of a city.

The conducted analysis augments previously published research results on smartness and confirms the need for further analysis of differentiation and dynamics of changes in the level of European cities' development compared to other world cities as well as a continued search for reasons of these phenomena and possible ways to improve this situation. In the future, the author intends to attempt to prepare the methodology for measuring smartness of European cities. The limitation of the research was the quantity of the source material and the objectivity of the source material selection method, which contributed to the generalized nature of the results.

\section{Acknowledgements}

The consideration presented in this article are the result of the research project S/WZ/5/2015 financed from Ministry of Science and Higher Education funds.

\section{References}

Albino, V., Berardi, U., \& Dangelico, R. M. (2015). Smart cities: definitions, dimensions, performance and initiatives. Journal of Urban Technology, 22(1), 3-21.

https://doi.org/10.1080/10630732.2014.942092

Aleksjeczuk, A., \& Sachpazidu-Wójcicka, K. (2015). Determinanty rozwoju e-usług w administracji publicznej w Polsce. Economics and Management, 1, 32-43.

Andrews, R., \& Van de Walle, S. (2013). New public management and citizens' perceptions of local service efficiency, responsiveness, equity and effectiveness. Public Management Review, 15(5), 762783. https://doi.org/10.1080/14719037.2012.725757

Antunes, P., Sapateiro, C., Zurita, G., \& Baloian, N. (2010). Integrating spatial data and decision models in an e-planning tool. Collaboration and Technology, 6257, 97-112.

https://doi.org/10.1007/978-3-642-15714-1_8

Baclija, I. (2012). Measuring new public management at the local level: experience from EU cities. Transylvanian Review of Administrative Sciences, 37, 23-37.

Bosch, P., Jongeneel, S., Rovers, V., Neumann, H. M., Airaksinen, M., \& Huovila, A. (2017). CITYkeys indicators for smart city projects and smart cities (pp. 10-13). Retrieved from http://nws.eurocities. eu/MediaShell/media/CITYkeysD14Indicatorsforsmartcityprojectsandsmartcities.pdf 
Braid, R. M. (2001). Spatial growth and redevelopment with perfect foresight and durable housing. Journal of Urban Economics, 49(3), 425-452. https://doi.org/10.1006/juec.2000.2199

Caragliu, A., Del Bo, C., \& Nijkamp, P. (2011). Smart cities in Europe. Journal of Urban Technology, 18(2), 65-82. https://doi.org/10.1080/10630732.2011.601117

Cohen, B. (2012). The smart city wheel. Retrieved from https://www.smart-circle.org/smart-city/boydcohen-smart-city-wheel/

Dall'O, G., Bruni, E., Panza, A., Sarto, L., \& Khayatian, F. (2017). Evaluation of cities' smartness by means of indicators for small and medium cities and communities: a methodology for Northern Italy. Sustainable Cities and Society, 34, 193-202. https://doi.org/10.1016/j.scs.2017.06.021

Dameri, R. P., \& Garelli, R. (2014, 18-19 September). Measuring business benefits and performance in smart cities. $9^{\text {th }}$ European Conference on Innovation and Entrepreneurship (pp. 137-144). Belfast, Ireland.

Dameri, R. P., \& Ricciardi, F. (2015). Smart city intellectual capital: an emerging view of territorial system innovation. Journal of Intellectual Capital, 16(4), 860-887.

https://doi.org/10.1108/JIC-02-2015-0018

Dirks, S., \& Keeling, M. (2009). A vision of smarter cities. How cities can lead the way into a prosperous and sustainable future. IBM global business services. Retrieved from https://www-03.ibm.com/ press/attachments/IBV_Smarter_Cities_-_Final.pdf

Duran-Sanchez, A., Rio-Rama, M. C., Sereno-Ramirez, A., \& Bredis, K. (2016). Sustainability and quality of life in smart cities: analysis of scientific production. In M. Peris-Ortiz, D. R. Bennett, \& D. Perez-Bustamante Yaba (Eds.), Sustainable smart cities. Creating spaces for technological, social and business development (pp. 159-181). Springer. https://doi.org/10.1007/978-3-319-40895-8_12

European Union. (2014). Mapping smart cities in the EU. Retrieved from www.europarl.europa.eu/ RegData/etudes/etudes/join/2014/507480/IPOL-ITRE_ET(2014)507480_EN.pdf

Fertner, C., Jørgensen, G., Nielson, T. A. S., \& Nilsson, K. S. B. (2016). Urban sprawl and growth management - drivers, impacts and responses in selected European and US cities. Future Cities and Environment, 2(9). https://doi.org/10.5334/s40984-016-0022-2

Flynn, N. (2012). Public sector management. London: Sage Publications.

Fox, M. S. (2015). The role of ontologies in publishing and analyzing city indicators. Computers, Environment and Urban System, 54, 266-279. https://doi.org/10.1016/j.compenvurbsys.2015.09.009

Giffinger, R. (2015). Smart city concepts: chances and risks of energy efficient urban development. International Conference Smart Cities and Green ICT Systems. International Conference on Vehicle Technology and Intelligent Transport Systems (pp. 3-16). https://doi.org/10.1007/978-3-319-27753-0_1

Giffinger, R., Fertner, C., Kramar, H., Kalasek, R., Pichler-Milanović, N., \& Meijers, E. (2007). Smart cities - ranking of European medium-sized cities. Vienna, Austria: Centre of Regional Science, Vienna University of Technology. Retrieved from http://www.smartcities.eu/download/smart_cities_final_report.pdf

Globalization and World Cities. (2016). The world according to GaWC 2016, Loughborough. Retrieved from http://www.lboro.ac.uk/gawc/world2016t.html

Guyon, I., \& Elisseeff, A. (2003). An introduction to feature extraction. Studies in Fuzziness and Soft Computing, 3, 1-25.

Hajduk, S. (2018). Instruments of spatial management in the context of sustainability - a multi-dimensional comparative analysis of the regional cities. Annual Set The Environmental Protection, 20, 1219-1233.

Hajduk, S. (2017). Bibliometric analysis of publications on city logistics in international scientific literature. Procedia Engineering, 182, 282-290. https://doi.org/10.1016/j.proeng.2017.03.194 
Hajduk, S. (2016). Smart specialization in the context of innovativeness in the regional spatial management. Proceeding of Selected Papers: Smart and Efficient Economy: Preparation for the Future Innovative Economy (pp. 542-549).

Harrison, C., Eckman, B., Hamilton, R., Hartswick, P., Kalagnanam, J., Paraszczak, J., \& Williams, P. (2010). Foundations for smarter cities. IBM Journal of Research and Development, 54(4), 1-16. https://doi.org/10.1147/JRD.2010.2048257

He, F. (2017, 16-18 June). Research on evaluation system of smart city construction based on analytic hierarchy process. $7^{\text {th }}$ International Conference on Education, Management, Information and Computer Science (pp. 886-891). Shenyang, China. https://doi.org/10.2991/icemc-17.2017.179

Hellwig, Z. (1968). Zastosowanie metody taksonomicznej do typologicznego podziału krajów ze względu na poziom rozwoju i strukturę kwalifikowanych kadr. Przeglad Statystyczny, 4, 3070-327.

Hollands, R. G. (2014). Critical interventions into the corporate smart city. Cambridge Journal of Regions, Economy and Society, 8(1), 61-77. https://doi.org/10.1093/cjres/rsu011

Howe, J., \& Langdon, C. (2002). Towards a Reflexive planning theory. Planning Theory, 1(3), 209-225. https://doi.org/10.1177/147309520200100302

Horelli, L. (2013). New approaches to urban planning. Insights from Participatory Communities, Aalto University publication series, Aalto-ST 10. Helsinki: Unigrafia Oy.

Hu, X., Li, X., Ngai, E., Leung, V., \& Kruchten, P. (2014). Multidimensional context-aware social network architecture for mobile crowdsensing. IEEE Communications Magazine, 52(6), 78-87. https://doi.org/10.1109/MCOM.2014.6829948

Institute for Urban Strategies. (2016). Global power city index 2016. The Mori Memorial Foundation, London-New York-Paris. Retrieved from http://www.mori-m-foundation.or.jp/pdf/GPCI2016_ en.pdf

IESE. (2017). IESE cities in motion. IESE Business School University Navara. Retrieved from https:// www.mos.ru/upload/documents/files/9743/IESECitiesinMotionIndexIESECitiesinMotionIndex. pdf.

Juniper Research. (2017). Smart cities - what's in it for citizens? Retrieved from https://newsroom.intel. com/wp-content/uploads/sites/11/2018/03/smart-cities-whats-in-it-for-citizens.pdf

Kearney, A. T. (2017). Global cities: leaders in a world of disruptive innovation. Retrieved from https:// www.atkearney.com/documents/10192/12610750/Global+Cities+2017+-+Leaders+in+a+World+o f+Disruptive+Innovation.pdf/c00b71dd-18ab-4d6b-8ae6-526e380d6cc4

Kobayashi Kaneko, A. R., Kniess, C. T., Ribeiro Serra, F. A., Nogueira Ferraz, R. R., \& Ruiz, M. S. (2017). Smart sustainable cities: bibliometric study and patent information. International Journal of Innovation, 5(1), 77-96. https://doi.org/10.5585/iji.v5i1.159

Komninos, N. (2006). The architecture of intelligent cities: integrating human, collective and artificial intelligence to enhance knowledge and innovation. $2^{\text {nd }}$ IET International Conference on Intelligent Environment (pp. 13-20). Athens. https://doi.org/10.1049/cp:20060620

Komninos, N. (2011). Intelligent cities: variable geometries of spatial intelligence. Intelligent Buildings International, 3(3), 172-188. https://doi.org/10.1080/17508975.2011.579339

Labra, R., \& Sanchez, M. P. (2013). National intellectual capital assessment models: a literature review. Journal of Intellectual Capital, 14(4), 582-607. https://doi.org/10.1108/JIC-11-2012-0100

Lesot, M. J. (2006). Outlier preserving clustering for structured data though kernels. Studies in classification, data analysis, and knowledge organization (pp. 462-469). https://doi.org/10.1007/3-540-31314-1_56

Lombardi, P., Giordano, S., Farouh, H., \& Yousef, W. (2012). Modelling the smart city performance. The European Journal of Social Science Research, 25(2), 137-149.

https://doi.org/10.1080/13511610.2012.660325 
Lynch, M. (2015). Standardized indicators for resilient cities: ISO 37120 \& The World Council on City Data. Retrieved from http://resilientcities2015.iclei.org/fileadmin/RC2015/files/pptx/Opening_Plenary_Lynch.pdf

Marsal-Llacuna, M. L. (2015). Building universal socio-cultural indicators for standardizing the safeguarding of citizens' rights in smart cities. Social Indicators Research, 130, 563-579. https://doi.org/10.1007/s11205-015-1192-2

McCarney, P. (2015). The evolution of global city indicators and ISO 37120: The first international standard on city indicators. Statistical Journal of the IAOS, 31, 103-110.

Młodak, A. (2006). Analiza taksonomiczna w statystyce regionalnej. Difin, Warszawa.

Nam, T., \& Pardo, T. A. (2011). Conceptualizing smart city with dimensions of technology, people, and institutions. Proceedings of the $12^{\text {th }}$ Annual International Digital Government Research Conference on Digital Government Innovation in Challenging Times (pp. 282-291). https://doi.org/10.1145/2037556.2037602

Neirotti, P., De Marso, A., Cagliano, A. C., Mangano, G., \& Scorrano, F. (2014). Current trends in smart city initiatives: some stylised facts. City, 38, 25-36. https://doi.org/10.1016/j.cities.2013.12.010

Ntungo, C. (2007). Quality culture in government: the pursuit a quality management model. Total Quality Management \& Business Excellence, 18(1-2), 135-145. https://doi.org/10.1080/14783360601052071

Panek, T. (2009). Statystyczne metody wielowymiarowej analizy porównawczej. Szkoła Główna Handlowa, Warszawa.

Pike, A., Rodriguez-Pose, A., \& Tomaney, J. (2006). Local and regional development. London-New York: Routledge, Taylor and Francis Group. https://doi.org/10.4324/9780203842393.ch49

Rathore, M. M., Ahmad, A., Paul, A., \& Rho, S. (2016). Urban planning and building smart cities based on the internet of things using Big Data analytics. Computer Networks, 101, 63-80. https://doi.org/10.1016/j.comnet.2015.12.023

Ricciardi, F., \& Za, S. (2014). Smart city research as in interdisciplinary crossroads: a challenge for management and organization studies. In L. Mola, F. Pennarola, \& S. Za (Eds.), From information to smart society: environment, politics and economics. Lecture notes in information system and organisation (pp. 163-171). Switzerland: Springer International Publishing. https://doi.org/10.1007/978-3-319-09450-2_14

Rios, P. (2008). Creating 'the smart city". Retrieved from http://archive.udmercy.edu:8080/bitstream/ handle/10429/393/2008_rios_smart.pdf?se

Roberge, I. (2013). Futures construction in public management. International Journal of Public Sector Management, 26(7), 534-542. https://doi.org/10.1108/IJPSM-06-2012-0074

Salet, W., \& Thornley, A. (2007). Institutional influences on the integration of multilevel governance and spatial policy in European city-regions. Journal of Planning Education and Research, 27(2), 188-198. https://doi.org/10.1177/0739456X07307207

Schuler, D. (2016). Smart cities plus smart citizens = civic intelligence? In G. Concilio \& F. Rizzo (Eds.), Human smart cities: rethinking the interplay between design and planning. Book Series: Urban and Landscape Perspectives (pp. 41-60). https://doi.org/10.1007/978-3-319-33024-2_3

Shapiro, J. M. (2006). Smart cities: quality of life, productivity, and the growth effects of human capital. Review of Economics \& Statistics, 88(2), 324-335. https://doi.org/10.1162/rest.88.2.324

Steele, R. (2014). ISO 37120 standard on city indicators - how they help city leaders set tangible targets, including service quality and quality of life. Centre for Liveable Cites, Singapore. Retrieved from http://www.clc.gov.sg/documents/Lectures/2014/CLC-2014-Rob-steele-Terry-Hill.pdf

The Mori Memorial Foundation. (2017). Global Power City Index 2017. GPCI $10^{\text {th }}$ Anniversary Special Edition, Tokyo 2017. Retrieved from http://mori-m-foundation.or.jp/pdf/GPCI2017_en.pdf 
Voytenko, Y., McCormick, K., Evans, J., \& Schliwa, G. (2016). Urban living labs for sustainability and cities in Europe: towards a research agenda. Journal of Cleaner Production, 123, 45-54.

https://doi.org/10.1016/j.jclepro.2015.08.053

World Council on City Data. (2017). Retrieved from http://open.dataforcities.org

Zanella, A., Bui, N., Castellani, A., Vangelista, L., \& Zorzi, M. (2014). Internet of things for smart cities. IEEE Internet of Things Journal, 1(1), 22-32. https://doi.org/10.1109/JIOT.2014.2306328

\section{APPENDIX 1. DOMAINS AND INDICATORS OF THE SMART CITY}

\begin{tabular}{|c|c|c|}
\hline Domains & $\begin{array}{l}\text { Number of } \\
\text { indicators }\end{array}$ & Indicators \\
\hline Economy & 3 & $\begin{array}{l}\text { City's Unemployment Rate; Assessed Value of Commercial and } \\
\text { Industrial Properties as a percentage of Total Assessed Value of } \\
\text { all Properties; Percentage of City Population Living in Poverty }\end{array}$ \\
\hline Education & 4 & $\begin{array}{l}\text { Percentage of Female School-aged Population Enrolled in } \\
\text { School; Percentage of Students Completing Primary Education: } \\
\text { Survival Rate; Percentage of Students Completing Secondary } \\
\text { Education: Survival Rate; Primary Education Student/teacher } \\
\text { Ratio }\end{array}$ \\
\hline Energy & 4 & $\begin{array}{l}\text { Total Residential Electrical Energy Use per Capita; Percentage } \\
\text { of City Population with Authorized Electrical Service; Energy } \\
\text { (Electricity) Consumption of Public Buildings per year; Per- } \\
\text { centage of Total Energy Derived from Renewable Sources, as a } \\
\text { Share of the City's Total Energy Consumption }\end{array}$ \\
\hline Environment & 3 & $\begin{array}{l}\text { Fine Particulate Matter (PM2,5) Concentration; Particulate } \\
\text { Matter (PM10) Concentration; Greenhouse Gas Emissions } \\
\text { Measured in Tonnes per Capita }\end{array}$ \\
\hline Finance & 1 & $\begin{array}{l}\text { Debt Service Ratio (Debt Service Expenditure as a Percentage } \\
\text { of a Municipality's Own-source Revenue) }\end{array}$ \\
\hline $\begin{array}{l}\text { Fire \& Emergency } \\
\text { Response }\end{array}$ & 3 & $\begin{array}{l}\text { Number of Firefighters per } 100000 \text { Population; Number of Fire } \\
\text { Related Deaths per } 100000 \text { Population; Number of Natural Di- } \\
\text { saster Related Deaths per } 100000 \text { Population }\end{array}$ \\
\hline Governance & 2 & $\begin{array}{l}\text { Volter Participation in Last Municipal Election (as a Percentage } \\
\text { of Eligible Volters); Women as a Percentage of Total Elected to } \\
\text { City-level Office }\end{array}$ \\
\hline Health & 4 & $\begin{array}{l}\text { Average Life Expectancy; Number of In-patient Hospital Beds } \\
\text { per } 100000 \text { Population; Number of Physicians per } 100000 \text { Pop- } \\
\text { ulation; Under Age Five Morality per } 1000 \text { Live Births }\end{array}$ \\
\hline Recreation & 0 & - \\
\hline Safety & 2 & $\begin{array}{l}\text { Number of police Officers per } 100000 \text { Population; Number of } \\
\text { Homicides per } 100000 \text { Population }\end{array}$ \\
\hline Shelter & 1 & Percentage of City Population Living in Slums \\
\hline Solid Waste & 3 & $\begin{array}{l}\text { Percentage of City Population with Regular Solid Waste collec- } \\
\text { tion (Residential); Total Collected Municipal Solid Waste per } \\
\text { Capita; Percentage of the City's Solid Waste that is Recycled }\end{array}$ \\
\hline
\end{tabular}




\begin{tabular}{|l|c|l|}
\hline \multicolumn{1}{|c|}{ Domains } & $\begin{array}{l}\text { Number of } \\
\text { indicators }\end{array}$ & \multicolumn{1}{|c|}{ Indicators } \\
\hline $\begin{array}{l}\text { Telecommunica- } \\
\text { tion \& Innovation }\end{array}$ & 2 & $\begin{array}{l}\text { Number of Internet Connections per 100000 Population; Num- } \\
\text { ber of Cell Phone Connections per 100000 Population }\end{array}$ \\
\hline Transportation & 4 & $\begin{array}{l}\text { Kilometers of High Capacity Public Transport System per } \\
\text { 100000 Population; Kilometers of Light Passenger Public Trans- } \\
\text { port System per 100000 Population; Annual Number of Public } \\
\text { Transport Trips Per Capita; Number of Personal Automobiles } \\
\text { per Capita }\end{array}$ \\
\hline Urban Planning & 1 & Green Area (Hectares) per 100000 Population \\
\hline Wastewater & 5 & $\begin{array}{l}\text { Percentage of the City Population Served by Wastewater Col- } \\
\text { lection; Percentage of the City's Wastewater that has Received } \\
\text { No Treatment; Percentage of the City's Wastewater Receiving } \\
\text { Primary Treatment; Percentage of the City's Wastewater Receiv- } \\
\text { ing Secondary Treatment; Percentage of the city's wastewater } \\
\text { receiving tertiary treatment }\end{array}$ \\
\hline $\begin{array}{l}\text { Water and Sanita- } \\
\text { tion }\end{array}$ & 4 & $\begin{array}{l}\text { Percentage of the City Population with Potable Water Supply } \\
\text { Service; Percentage of the City Population with Sustainable } \\
\text { Access to an Improved Water Source; Percentage of Popula- } \\
\text { tion with Access to Improved Sanitation; Total Domestic Water } \\
\text { Consumption per Capita (Liters/day). }\end{array}$ \\
\hline
\end{tabular}

Note: author's elaboration on the basis of (World Council on City Data, 2017). 